This article has been scanned by iThenticat No plagiarism detected

Volume 3, Issue 3, June 2021

p. $13-22$

\title{
THE REALITY OF ADMINISTRATIVE CREATIVITY IN THE OMAN EDUCATION INSTITUTION: OPPORTUNITY AND CHALLENGES
}

http://dx.doi.org/10.47832/2757-5403.3-3.2

\section{Khaled Mohamed ALBATTASHI 1}

\begin{abstract}
:
This study aims to identify the administrative creativity in Oman Education Institutions. This study aims also to identify the opportunities and challenges in Oman education institutions. The problem statement is to reduce the level of administrative creativity in Oman institutions in general, in Oman education institution in particular. The importance of study is to highlights on the reality the administrative creativity in Oman Education Institutions. The study follows descriptive and analytical method approach to describe and analysis the reality the administrative creativity in Oman Education Institutions. The study results are there a lot of requirement should have to achieve the administrative creativity. The study recommend that recommendation of 2040 should publicity in developing the creativity abilities of employees in Oman Education Institutions.
\end{abstract}

Key words: Administrative Creativity, Administrative Creativity Opportunities, Administrative Creativity Challenges, Oman.

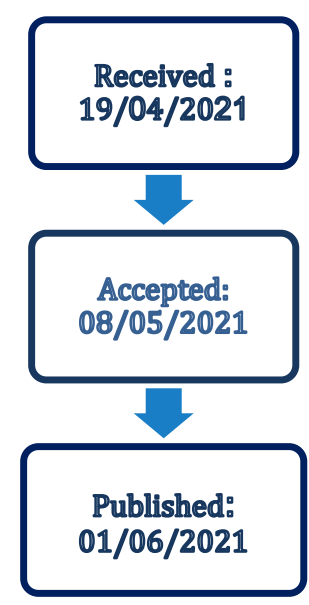

\footnotetext{
${ }^{1}$ Researcher, Sultanate of Oman, albatashi58@gmail.com, https://orcid.org/0000-0001-8411-3384
} 
واقع الإبداع الإداري في مؤسسات التعليم بسلطنة عمان: الفرص والتحديات

خالا محمد البطاشي 2

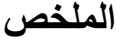

تهذف الدراسة إلى التعرف على واقع الإبداع الإداري في مؤسسات التعليم بسلطنة عمان،

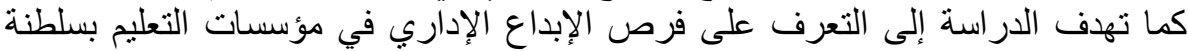

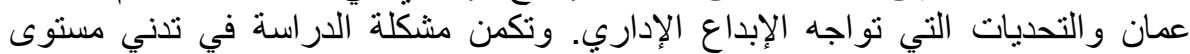

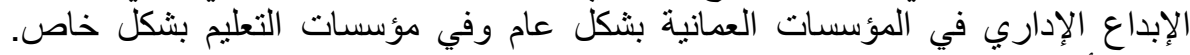

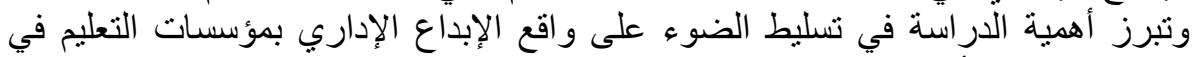

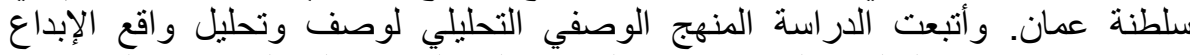

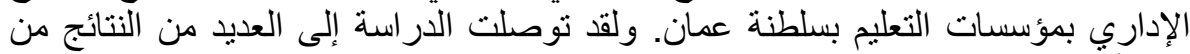

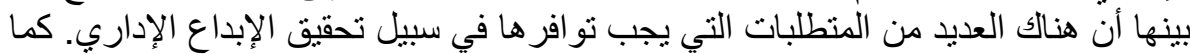
أوصت الدراسة بضرورة تعميم توصيات خطة 2040 بشأن تطوير القدرات الإبداعية اللعاملين بمؤسسات التعليم بسلطنة عمان. الإندان. الكلمات المفتاحية: الإبداع الإداري، فرص الإندان. الإبداع الإداري، تحديات الإبداع الإداري،

سلطنة عمان.
\end{abstract}

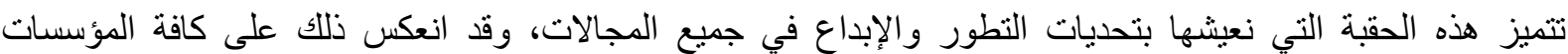

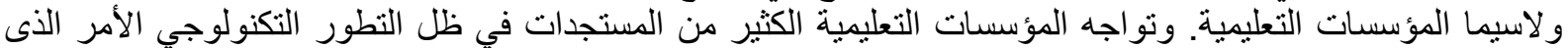

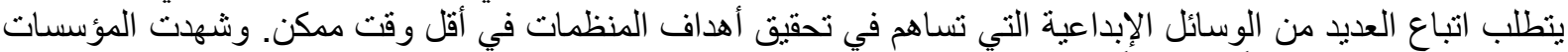

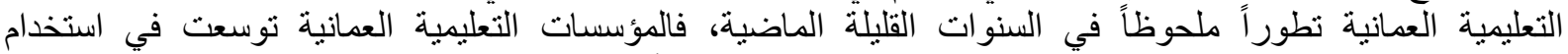

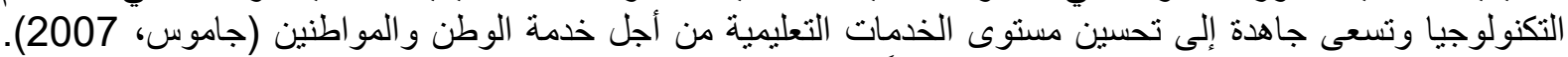

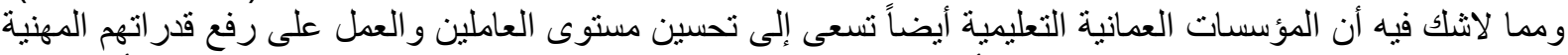

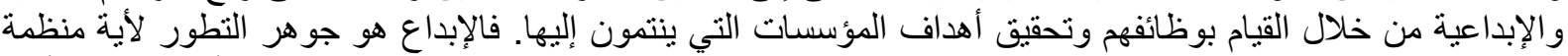

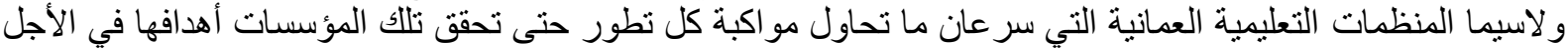

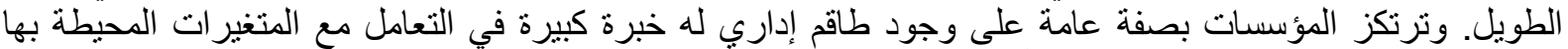

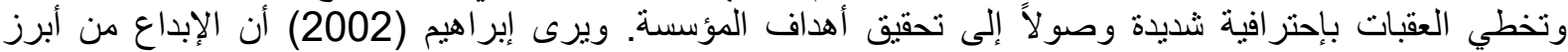

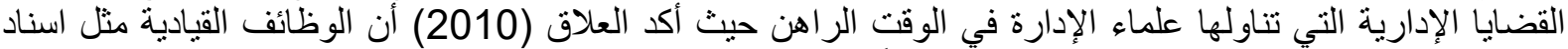

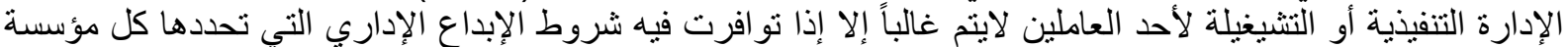

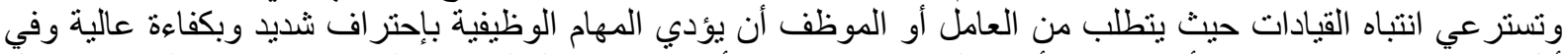

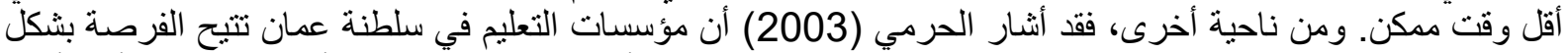

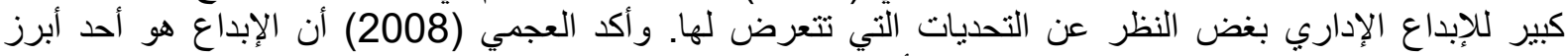

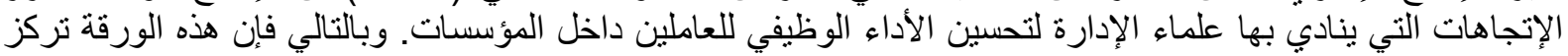

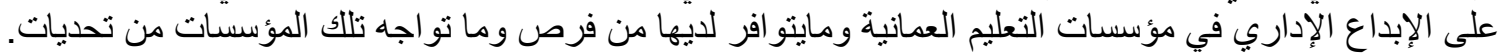

مشكلة الدر اسة

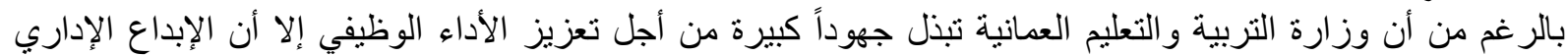

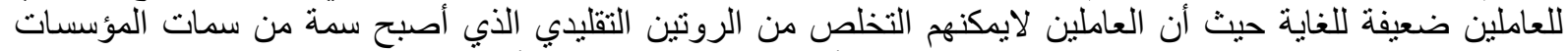

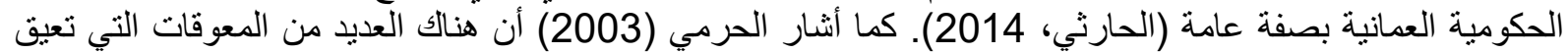

albatashi58@gmail.com الباحث، سلطنة عمان، 


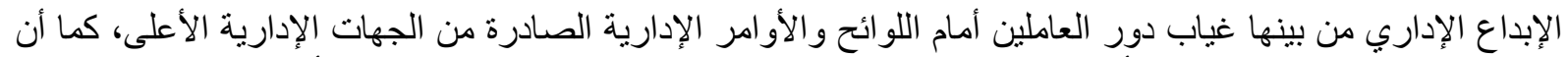

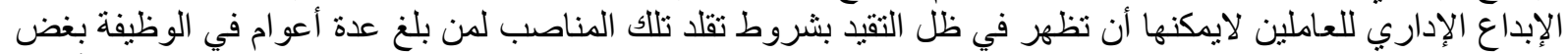

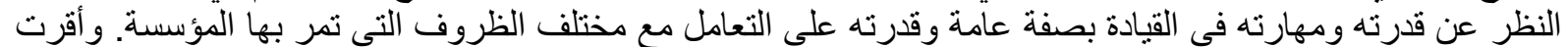

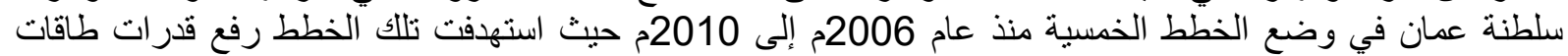

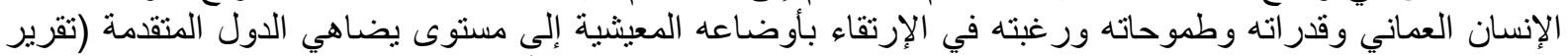

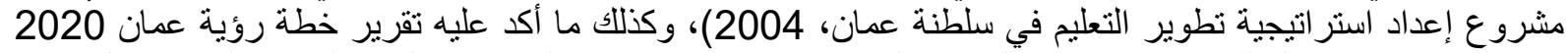

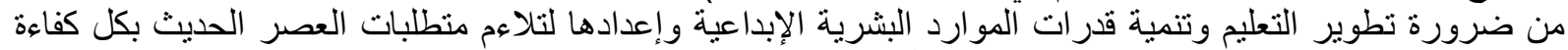

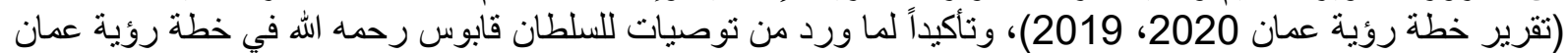

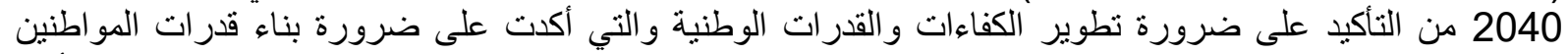

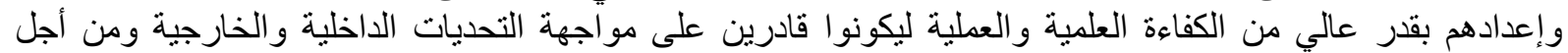

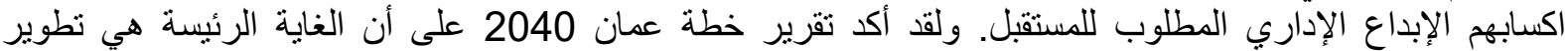

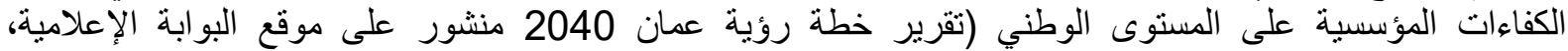

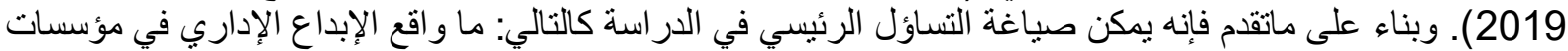

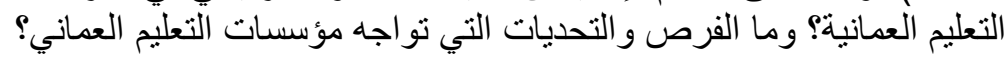

أهداف الاراسة تهدف هذه الدراسة إلى التعرف على و اقع الإبداع الإداري في مؤسسات التعليم العمانية و الفرص المتاحه و التحديات التي تو اجه تللك المؤسسات.

\section{أهمية الاراسة}

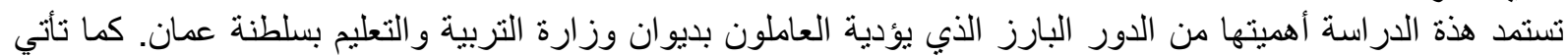

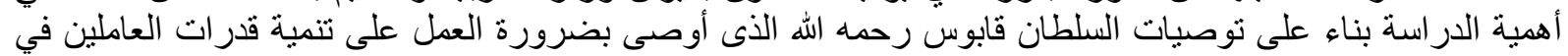

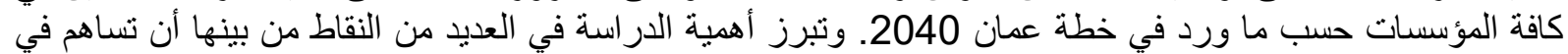

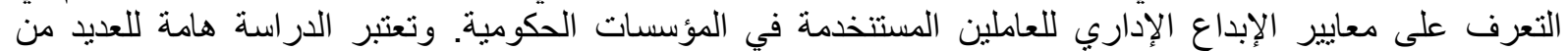

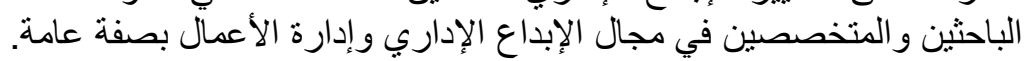

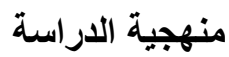

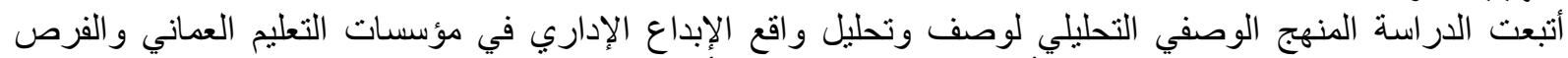

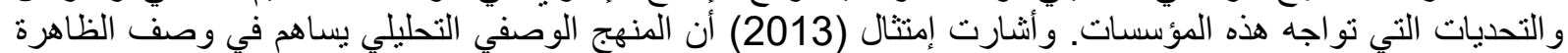

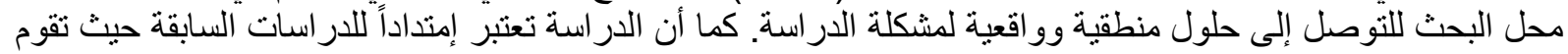

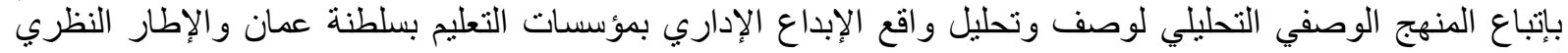
ل الإبداع الإداري.

مفهوم الإبداع الإداري

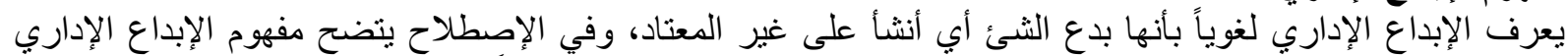

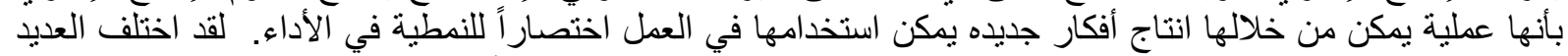

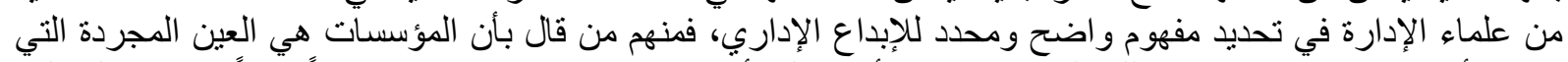

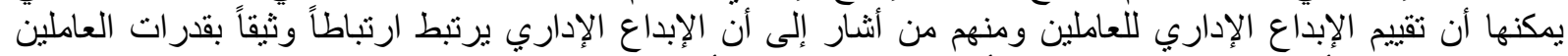

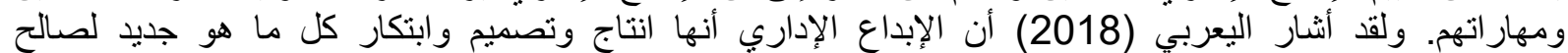

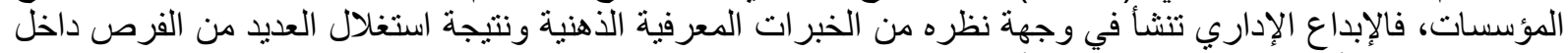

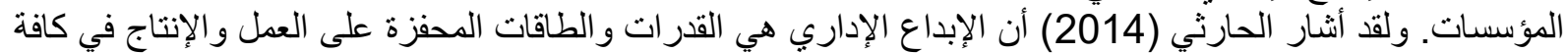

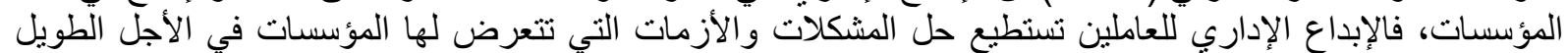

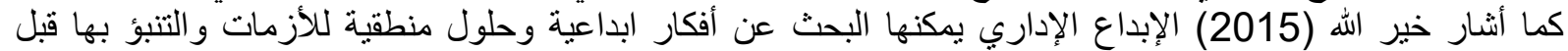

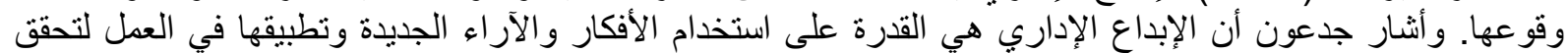

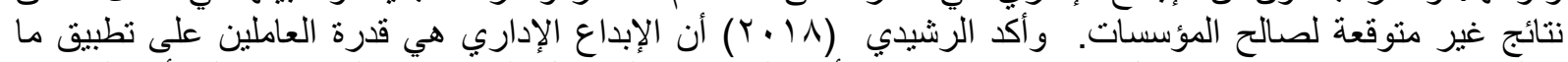

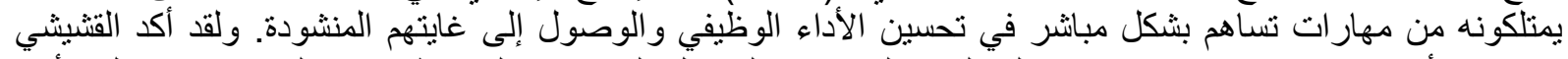

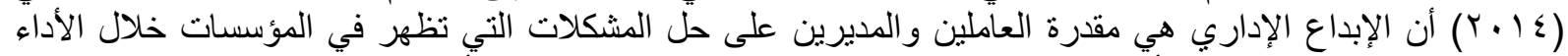

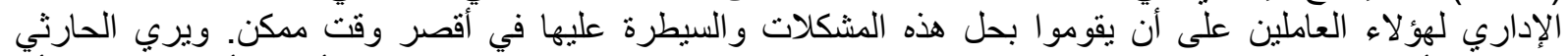
(2014) أن الإبداع الإداري هي قدرة العاملين في المؤسسات من استخدام وسائل غير نمطية ألثاء أثناء الأداء الإداري وأن وأن 
تللك الوسائل غير النمطية يمكن استخدامها كلما تعرضت المؤسسات للأزمات. و أثنار خير الله (2015) أن الإبداع

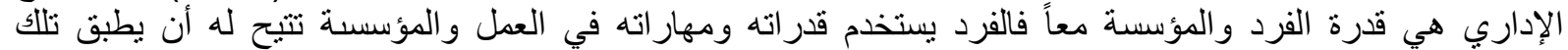

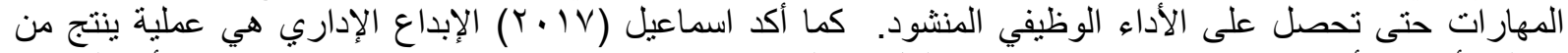

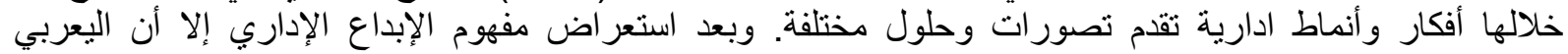

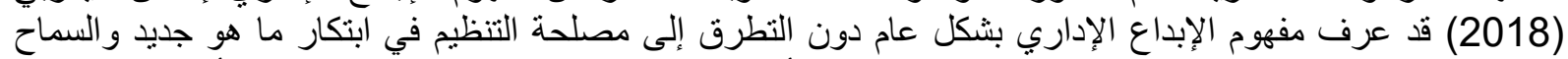

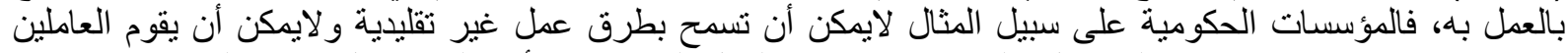

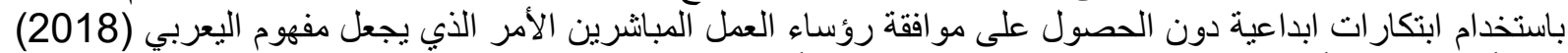

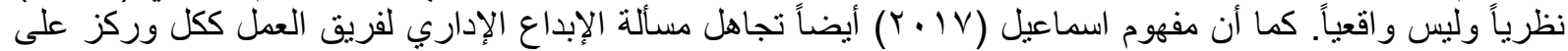

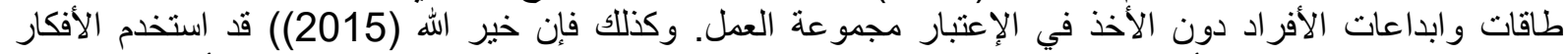

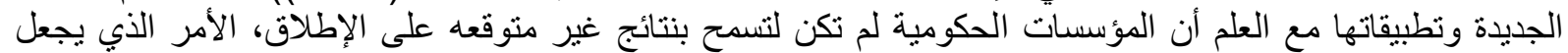

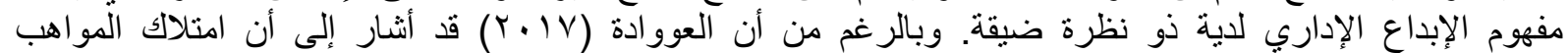

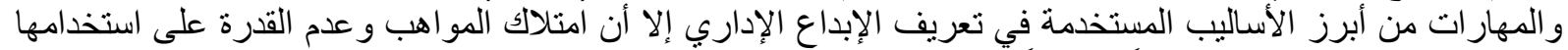

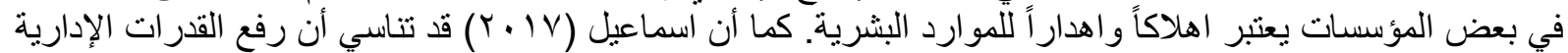

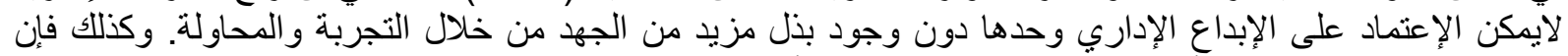

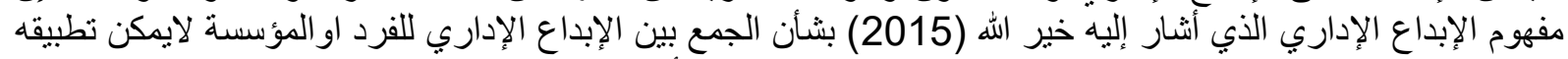

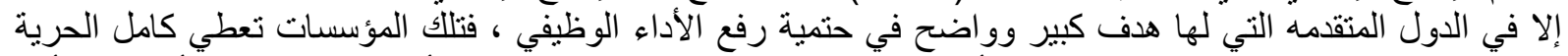

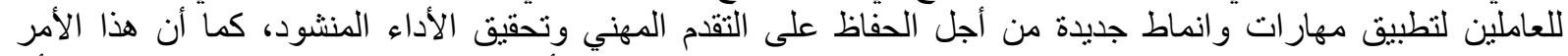

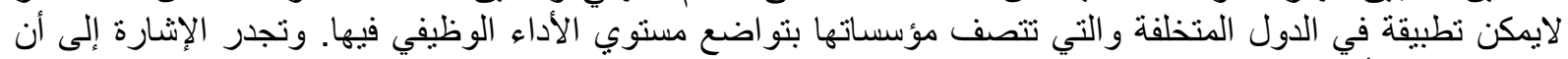

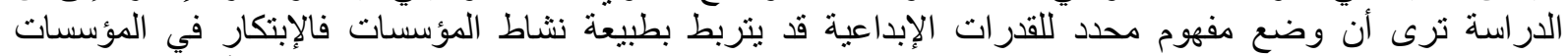

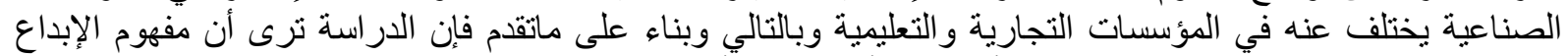

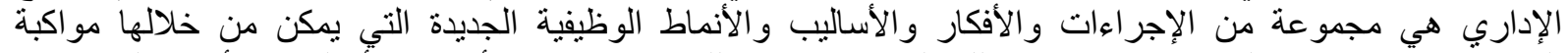

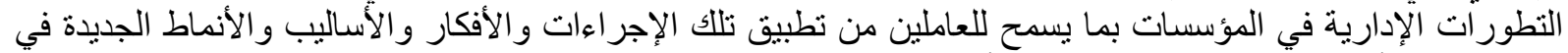

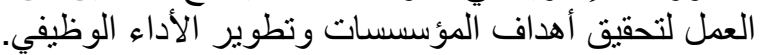

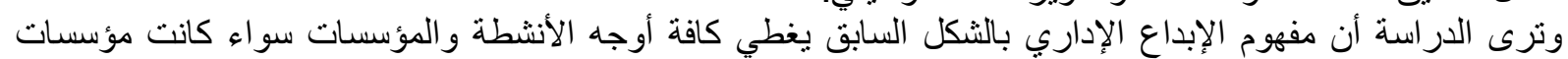

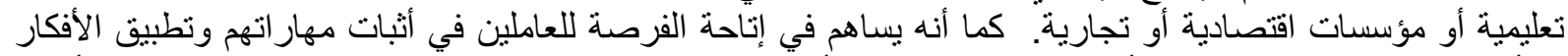

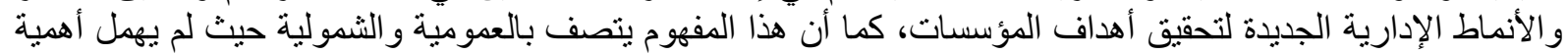

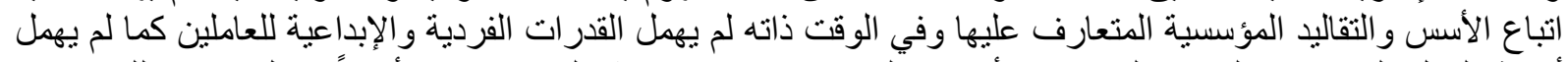

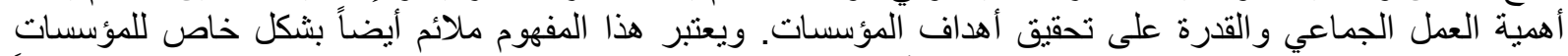

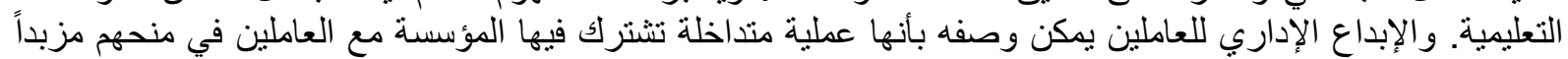

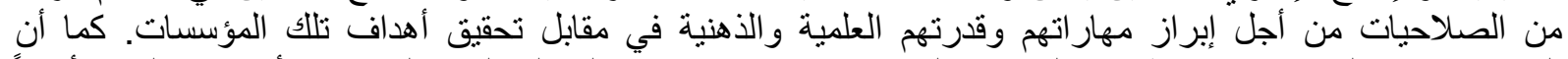

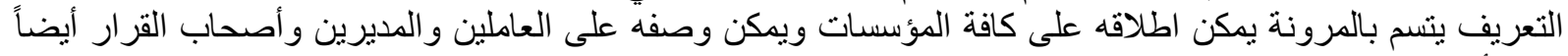

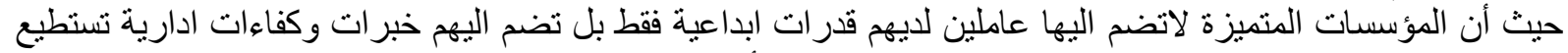

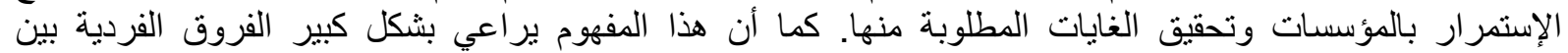
العاملين، فكل العاملين لديهم قدر ات وطاقات ابداعية تظهر بشكل طبيعي عند بروز الغيات أزمات وات وأحداث داخل المؤسيسات.

أهمية الإبداع الإداري

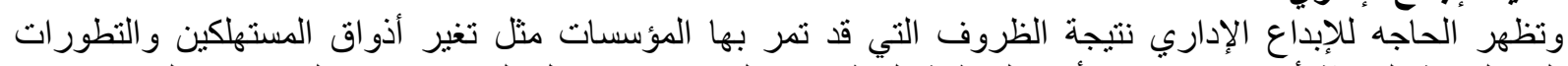

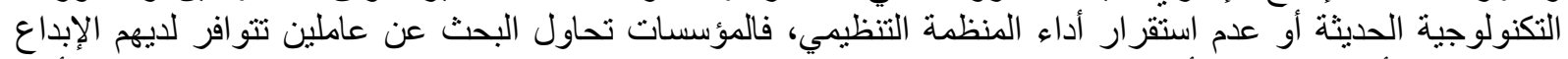

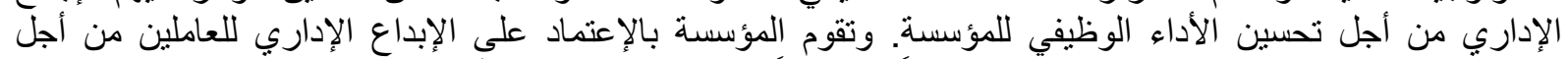

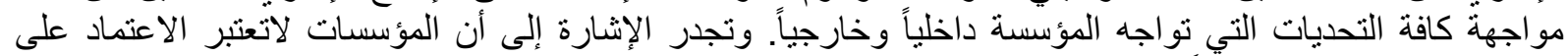

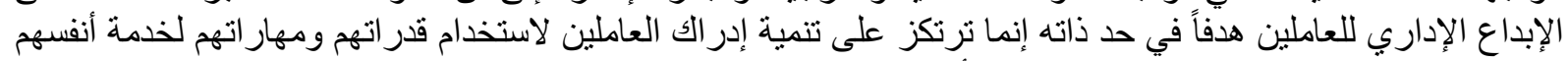

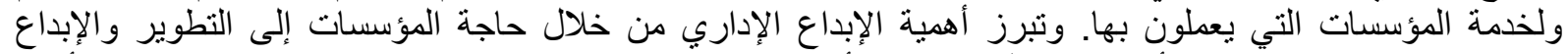

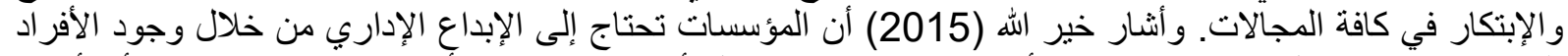

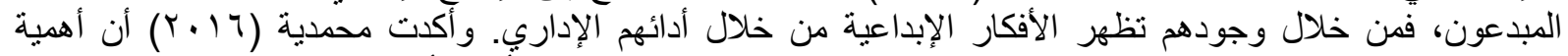

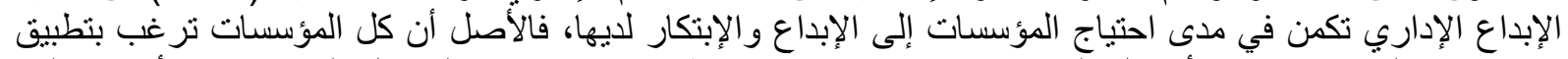

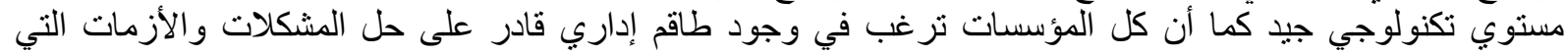




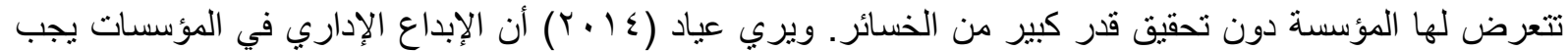

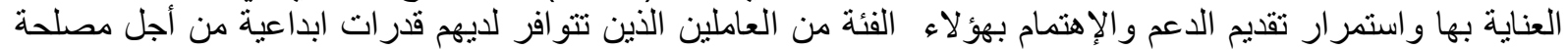

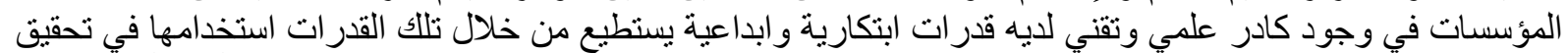

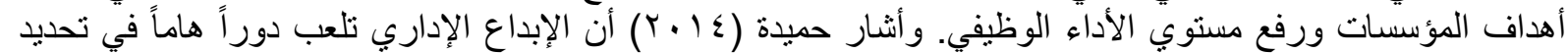

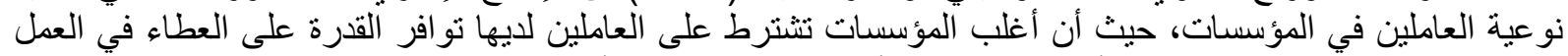

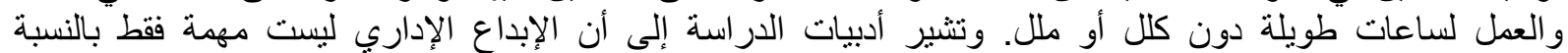

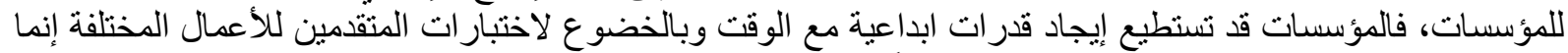

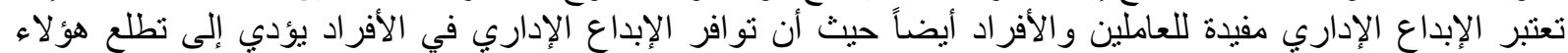

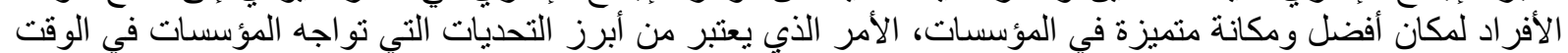

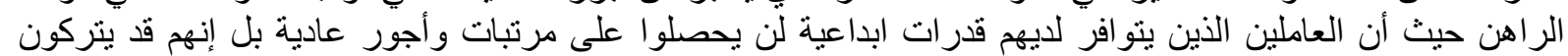

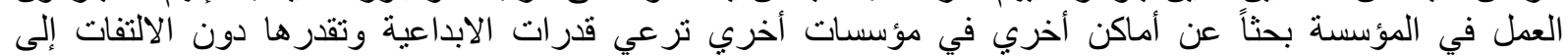

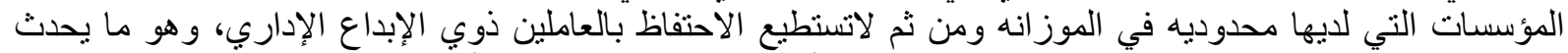

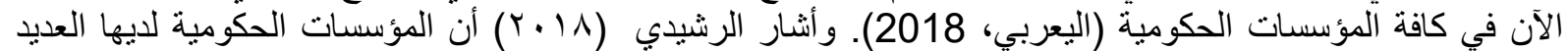

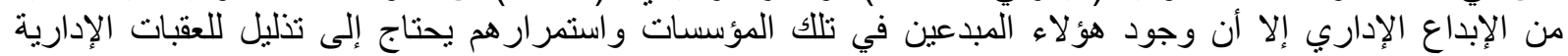

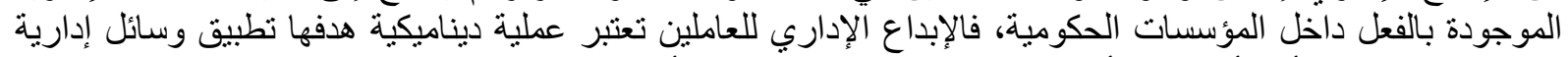

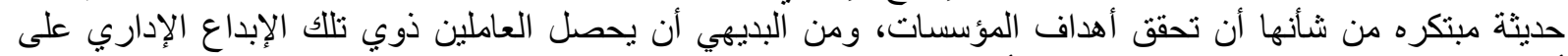

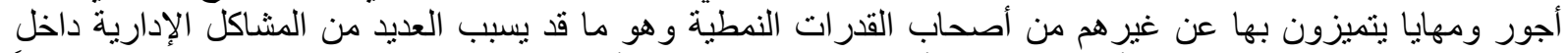

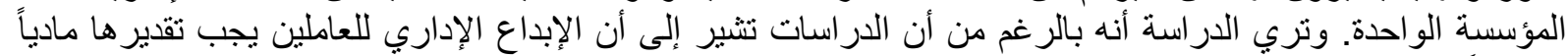

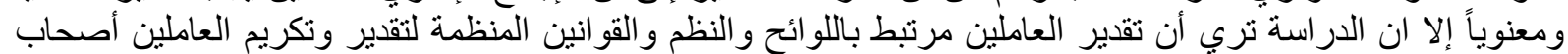

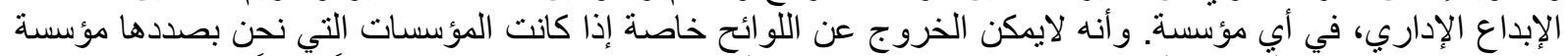

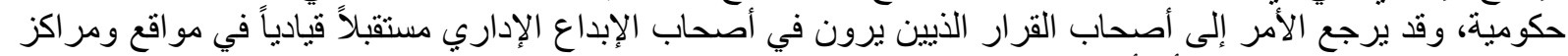

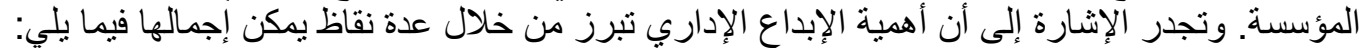

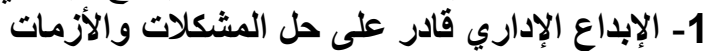

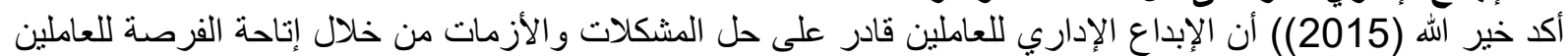

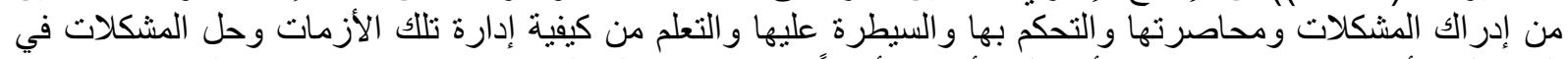

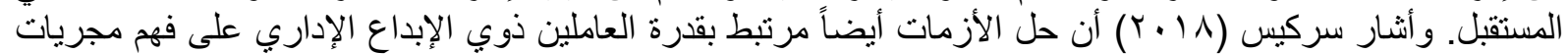

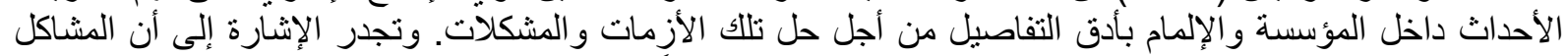

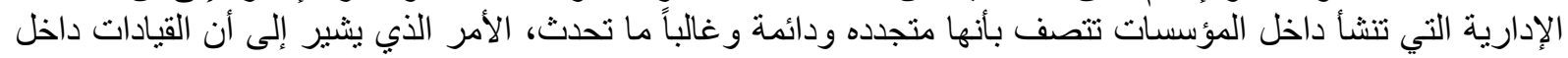

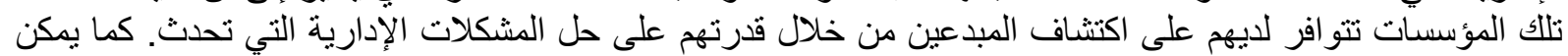

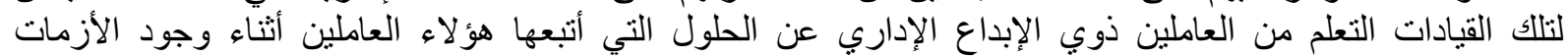

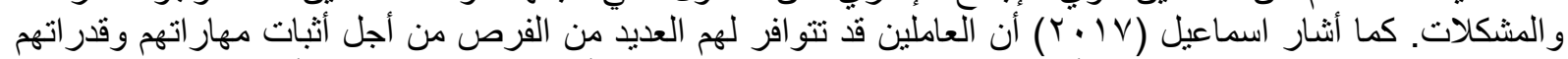

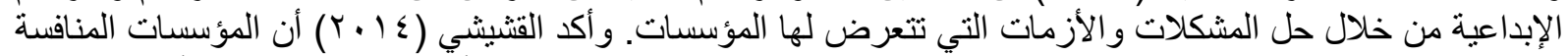

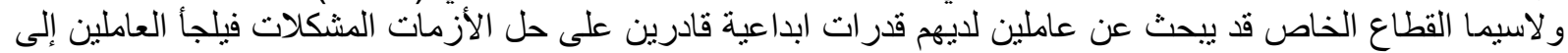

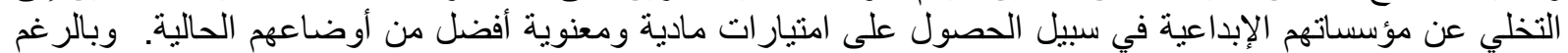

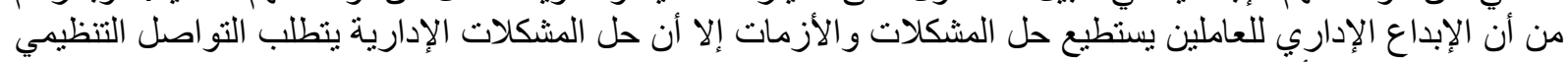

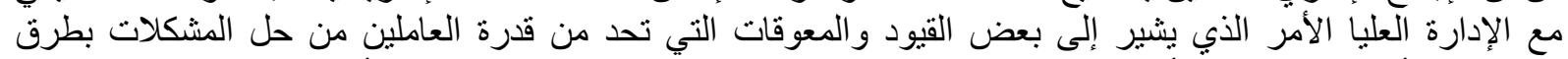

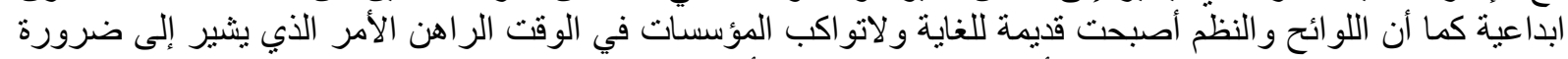

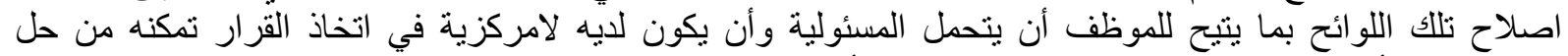

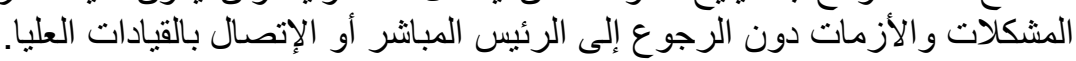

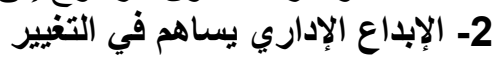

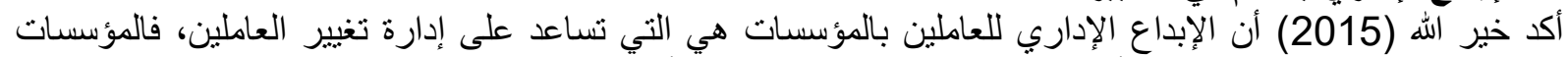

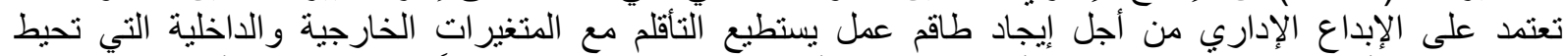

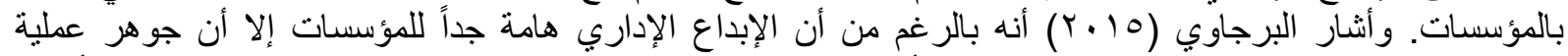

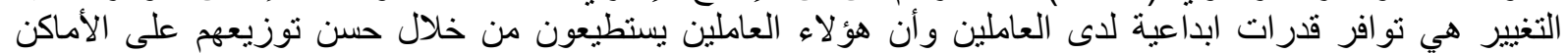

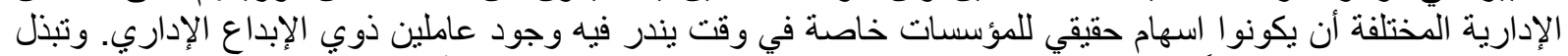

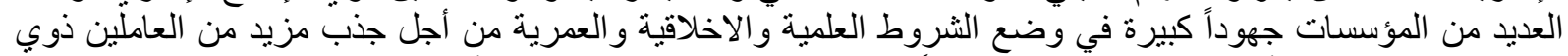

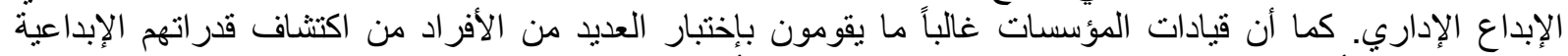

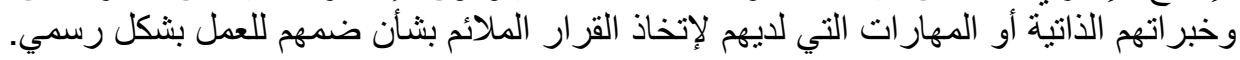


وتساعد إدارة الموارد البشرية و إدارة شئون الأفراد بتحديد الإحتياجات من العاملين المطلوب انضمامهم للمؤسسة بشكل

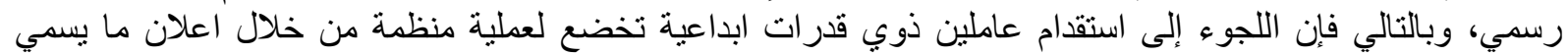

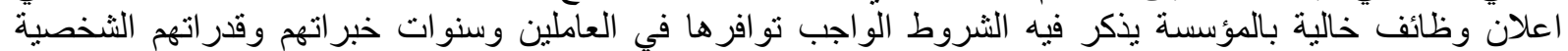

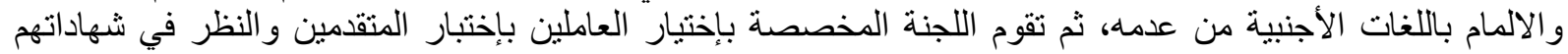

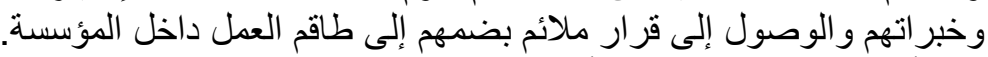

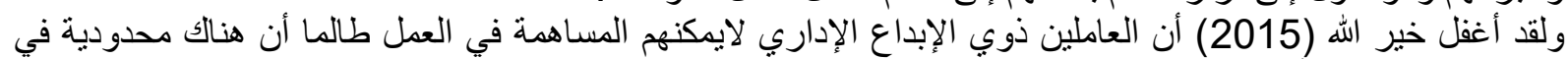

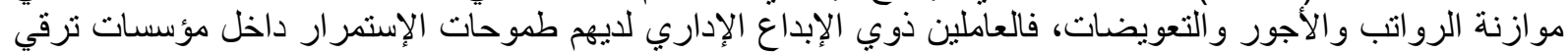

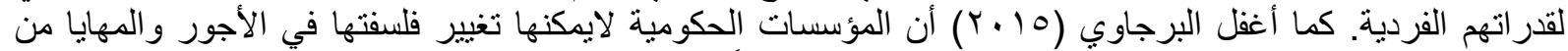

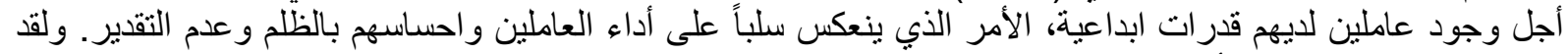

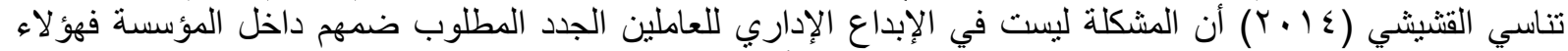

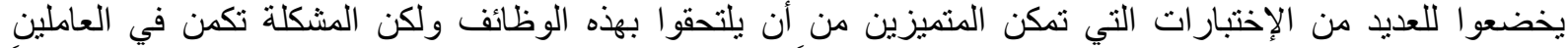

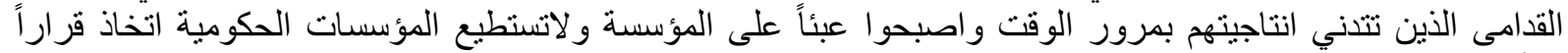
بشأنهم. وترى الدراسة إن اختلاط العاملين القدامى بالعاملين الجدد قد يخلق العالئ مشكلة إدارية كبيرة فالعاملين القدامى بطالبون

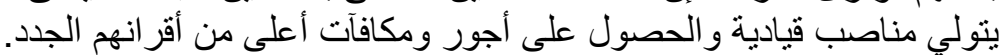

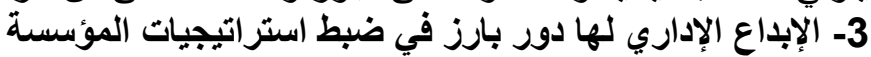

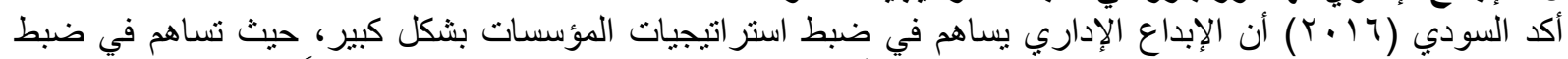

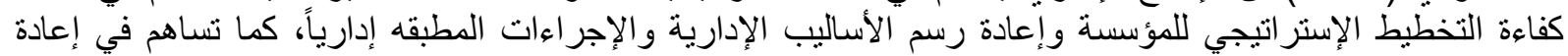

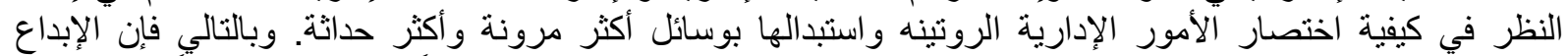

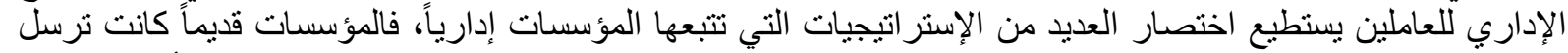

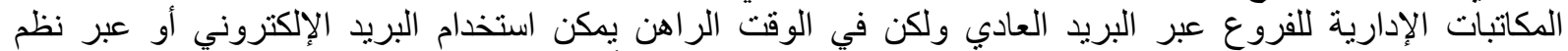

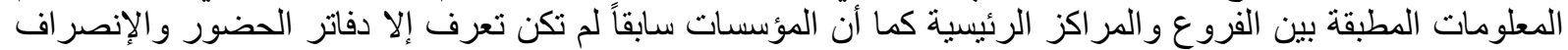

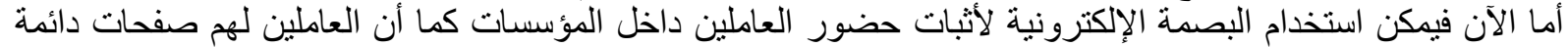

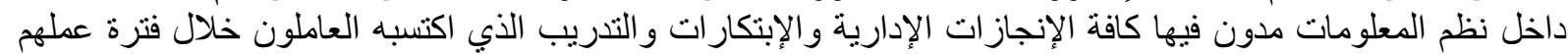

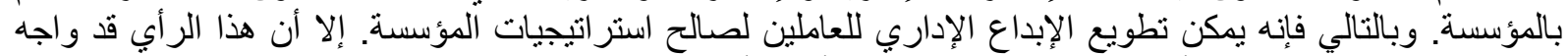

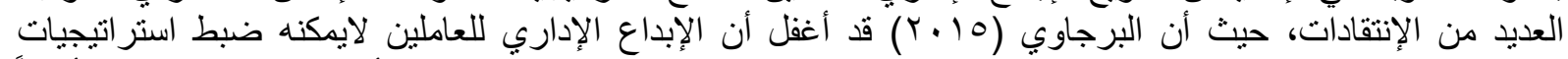

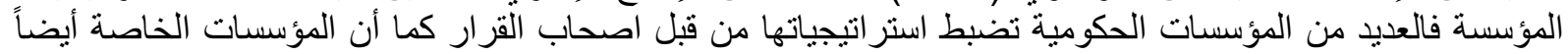

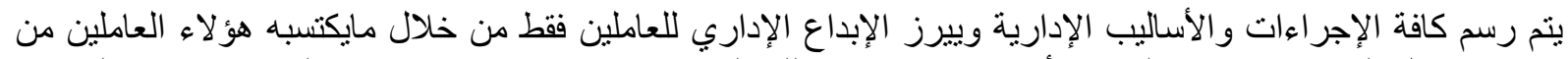

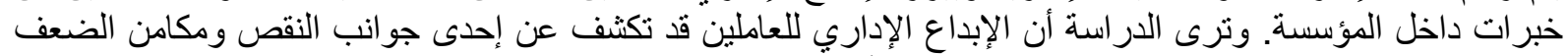

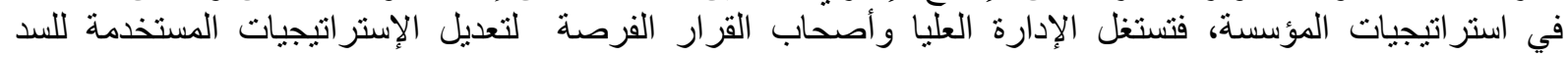
الثغرات في الإستراتيجيات المستخدمة. وبالتالي فإن وجود الإبداع الإداري للعاملين بساهم في ضبط استراتيجيات التيات التيات المؤسسة بشكل كبير.

\section{فرص تنمية الإبداع الإداري}

أكد العديد من علماء الإدارة أن أساليب تتمية الإبداع الإداري عداري الإديدة ومتتوعة، وقد تختلف بإختلاف طبيعة النشاط الإداري

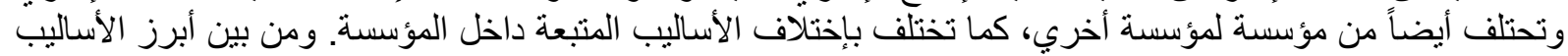

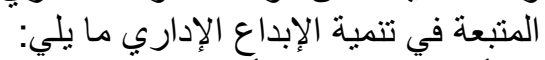

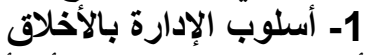

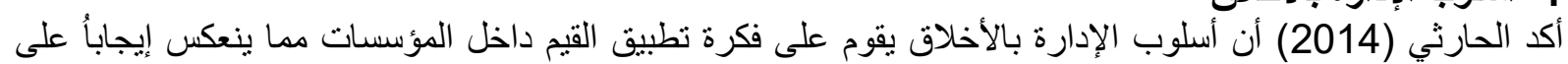

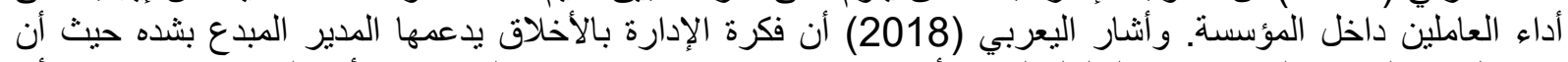

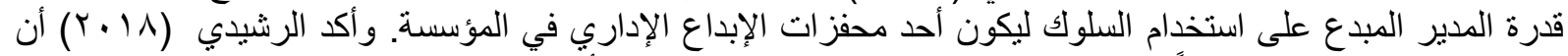

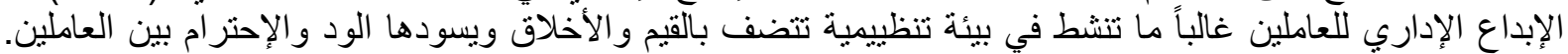

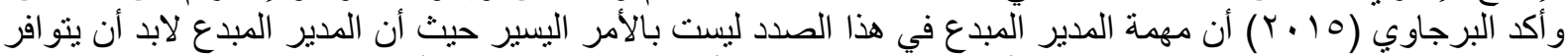

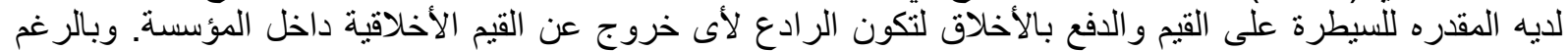

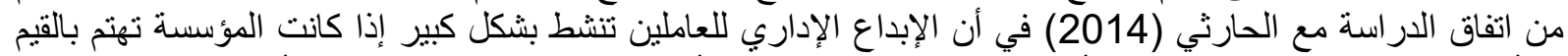

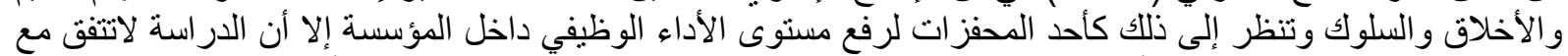

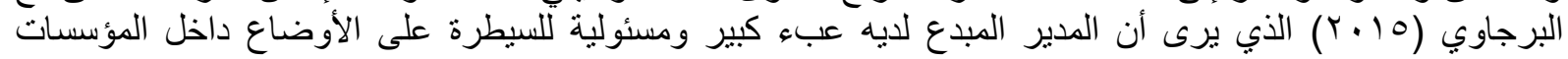


التعليمية، فالمدير المبدع إن كانت لدية مسئولية للسيطرة على انماط السلوك فمن يرسي تلاكل القو اعد هي المؤسسة التعليمية

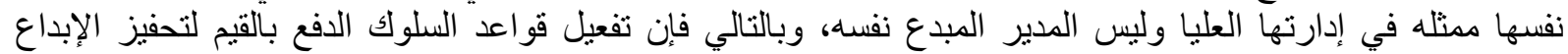

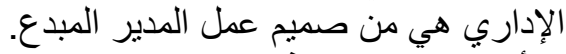

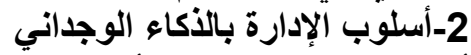

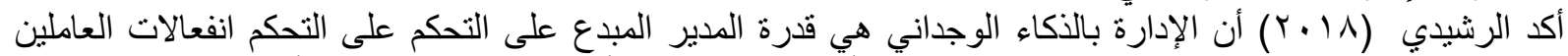

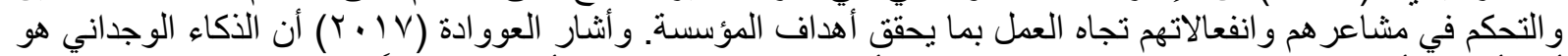

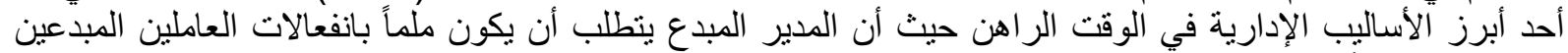

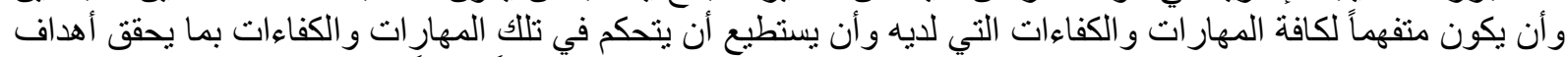

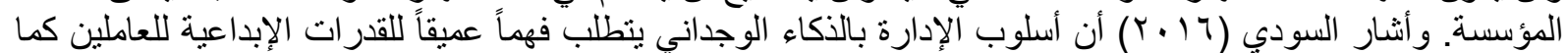

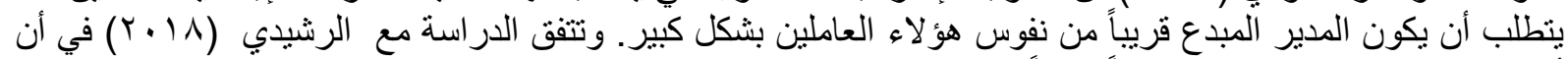

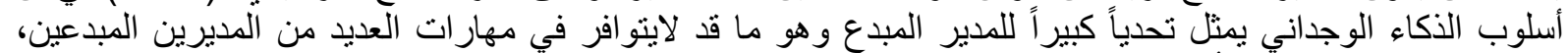

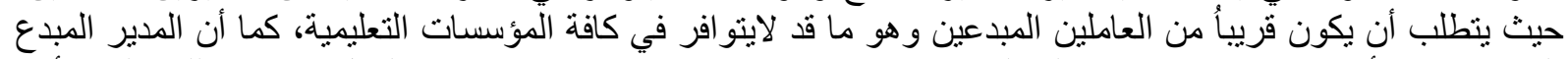

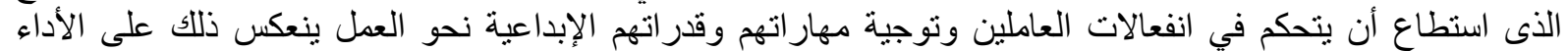

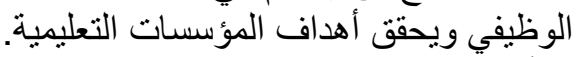

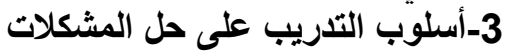

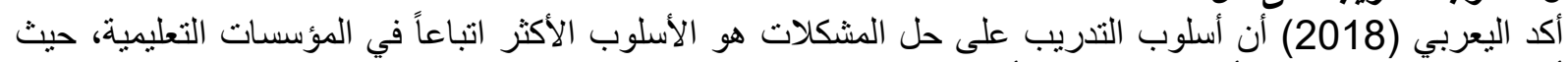

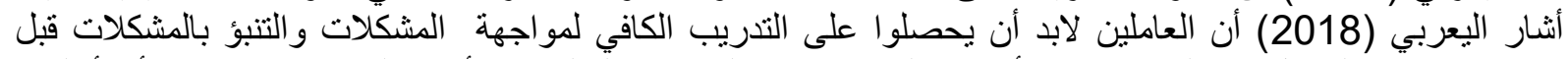

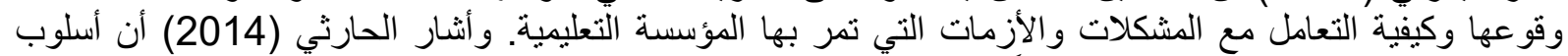

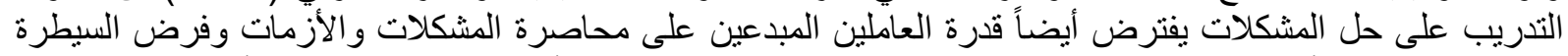

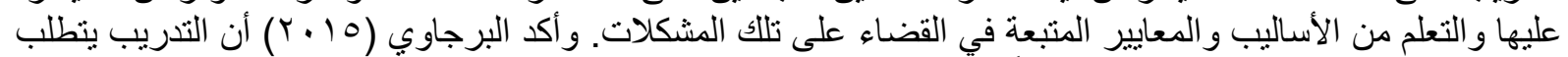

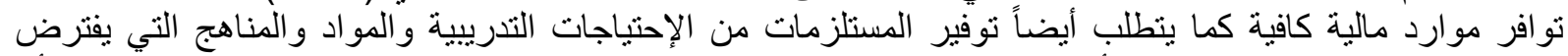

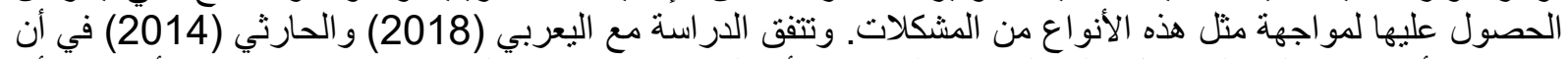

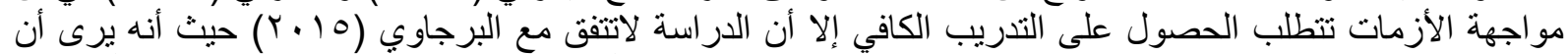

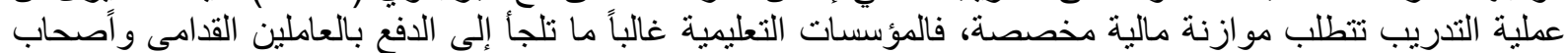

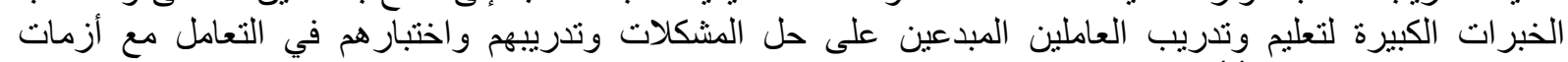

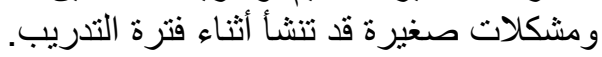

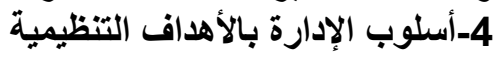

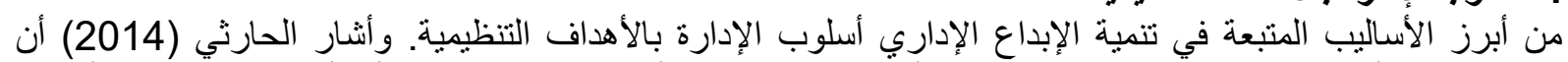

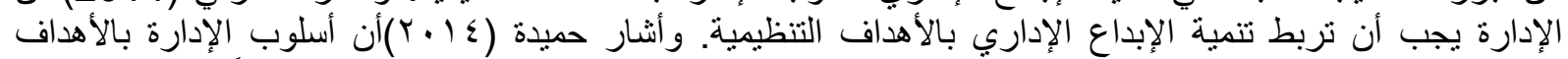

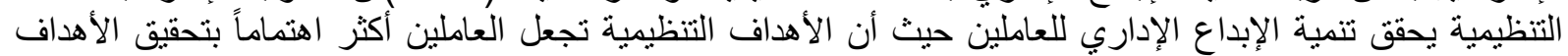

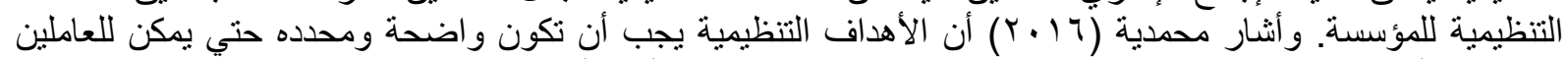

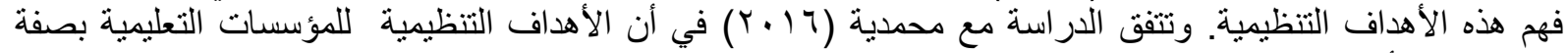

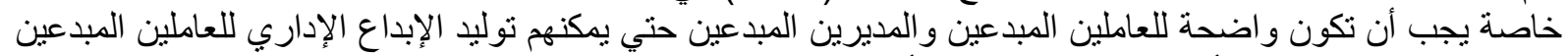
بشكل مباشر لتحقيق تلأك الأهداف ولرفع مستوى الأداء الواء الوظيفي. 5-أسلوب العصف الذهني

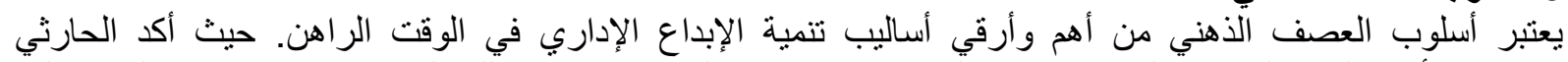

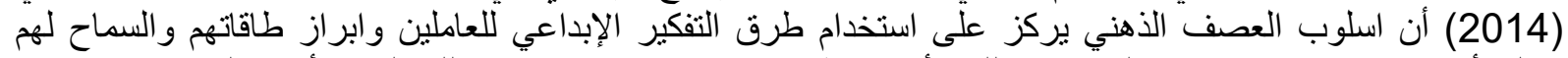

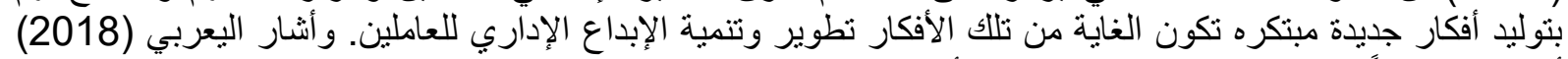

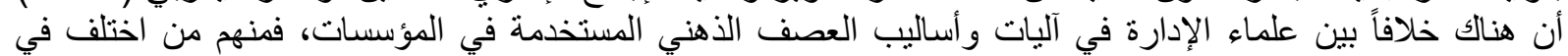

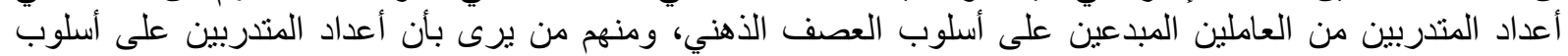

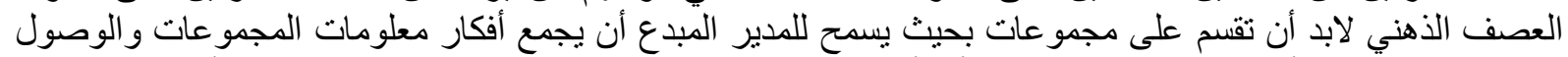

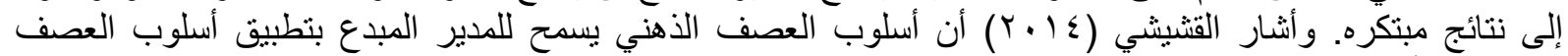

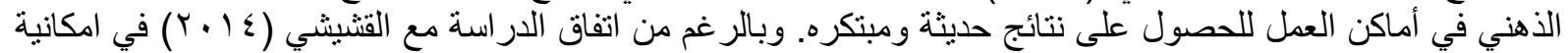

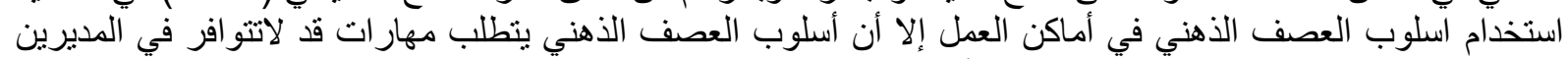

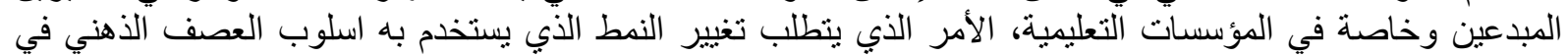

المؤسسات التعليمية. 


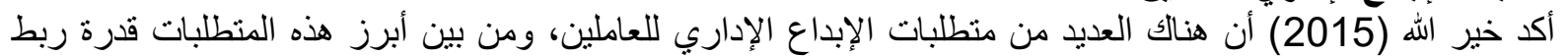

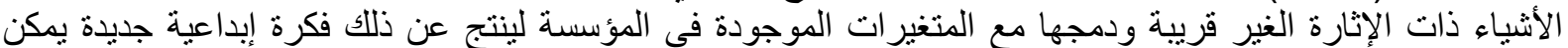

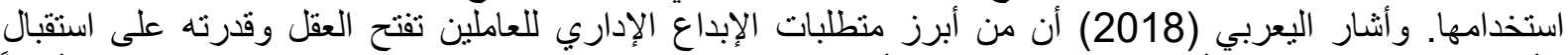

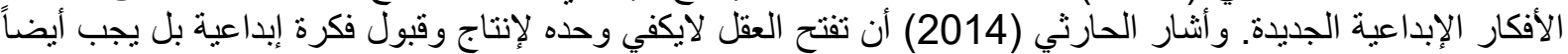

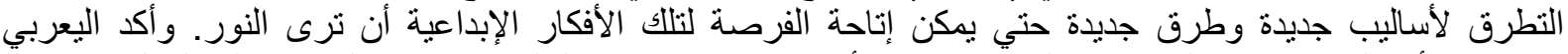

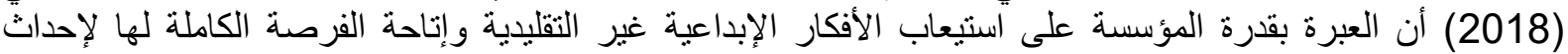

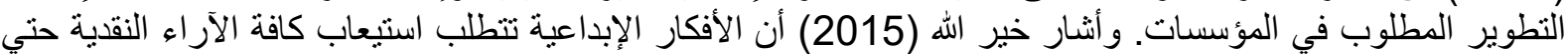

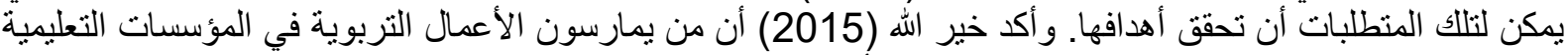

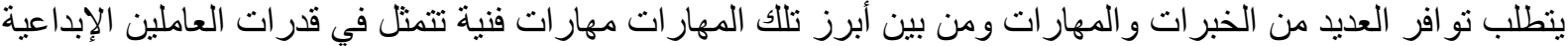

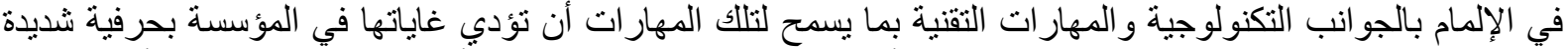

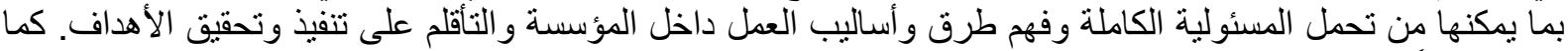

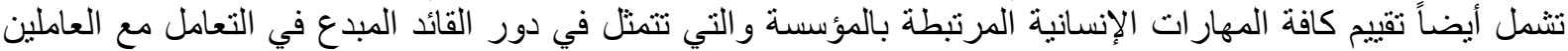

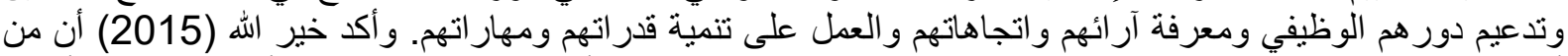

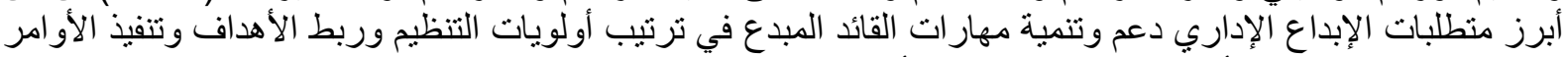

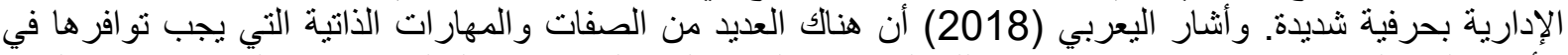

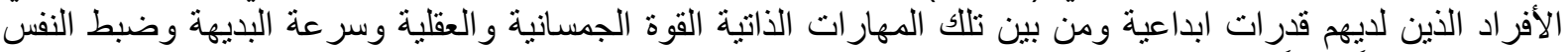

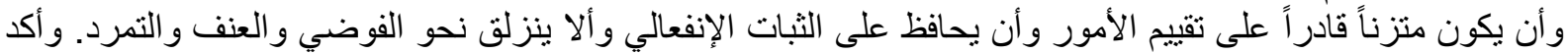

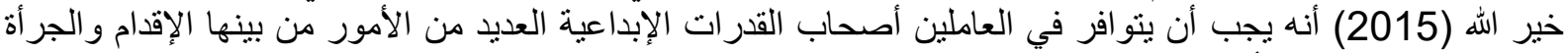

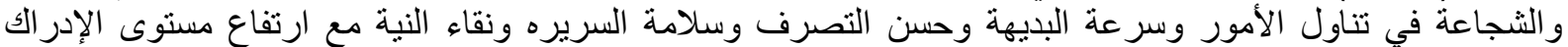

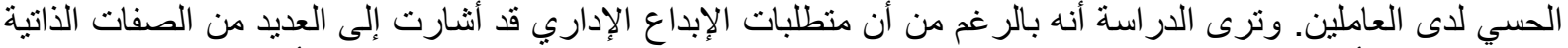

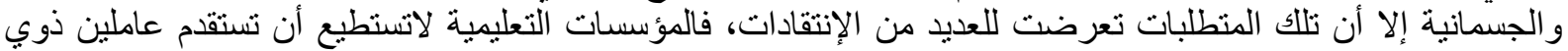

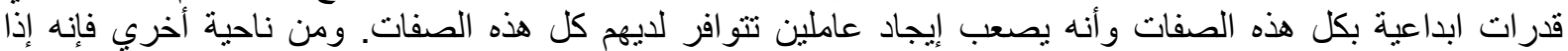

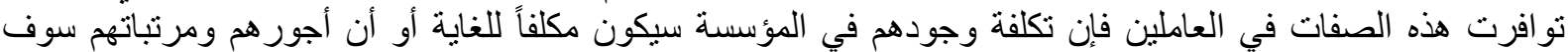

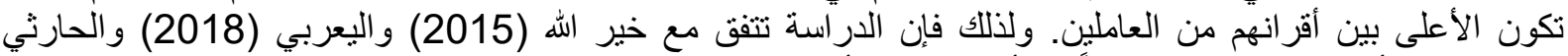

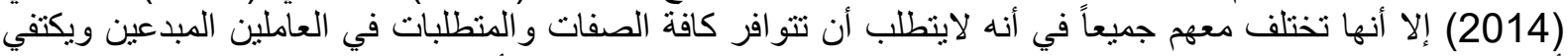
أن توجد صفات تتعلق بقدرة العاملين على إنجاز المهام الوظيفية والإنتفاع من أدور اهم الوظيفية بشكل مباتشر لتحقيق التهيق

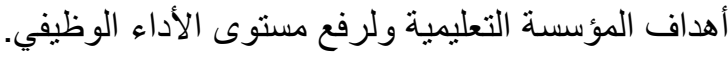

\section{معوقات وتحديات الإبداع الإداري}

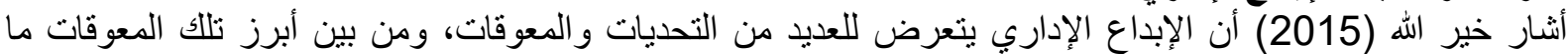

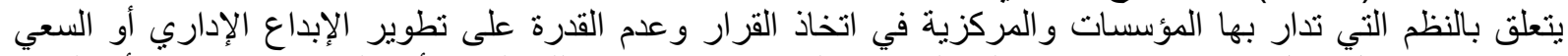

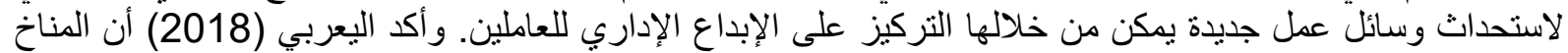

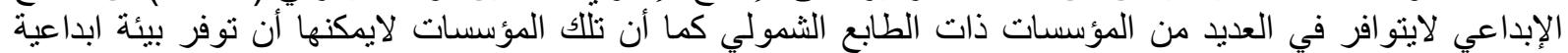

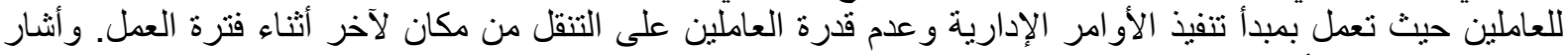

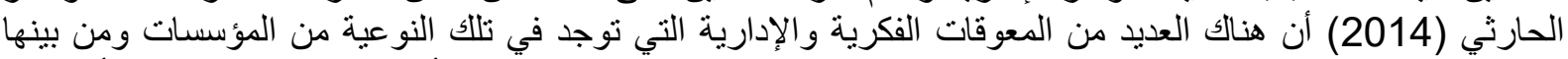

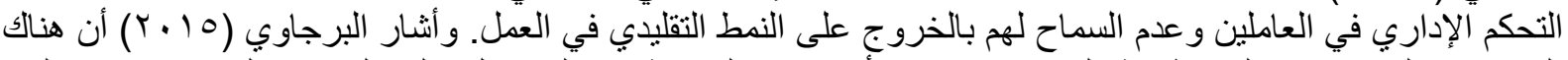

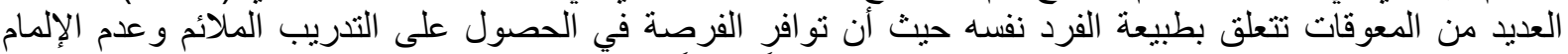

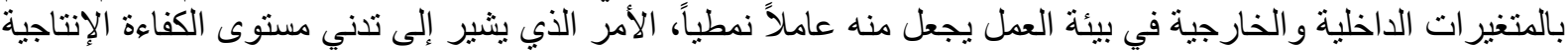

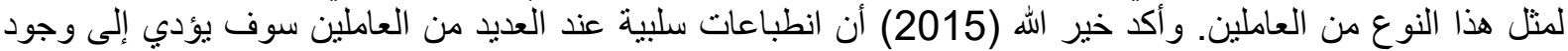

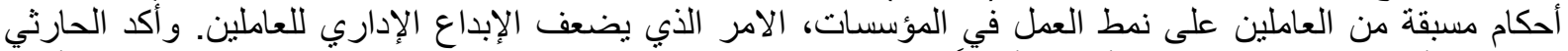

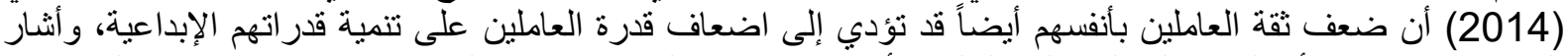

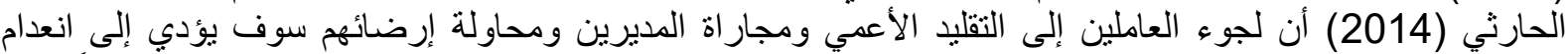

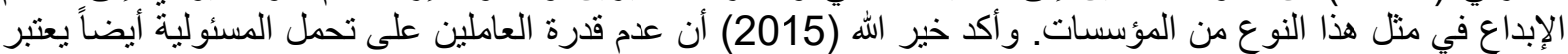

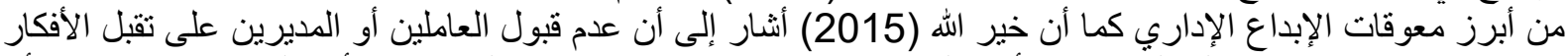

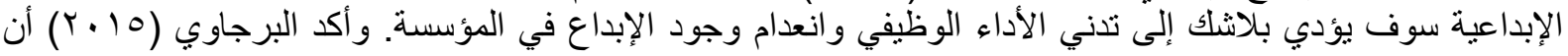




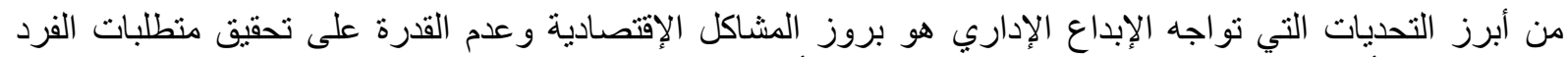

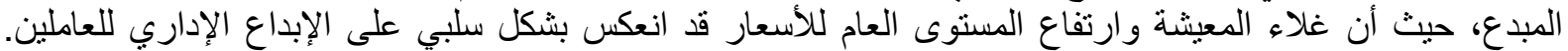

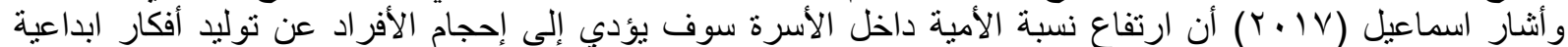

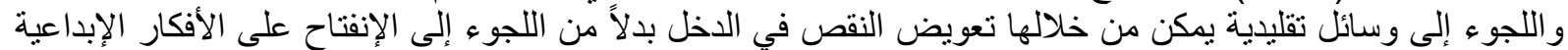

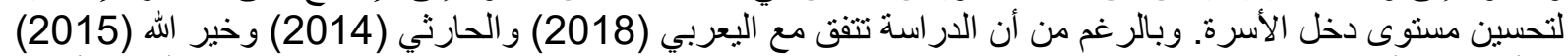

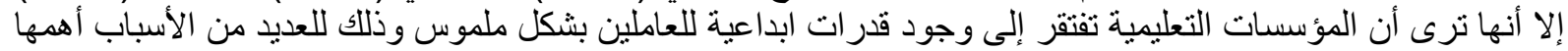

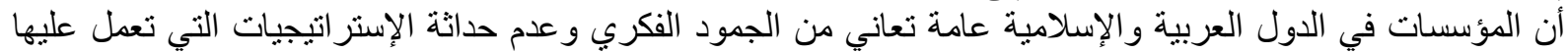

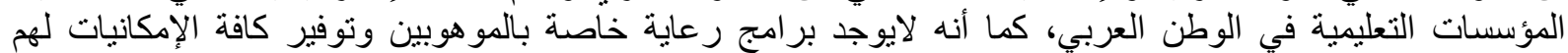

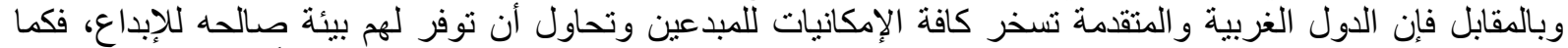

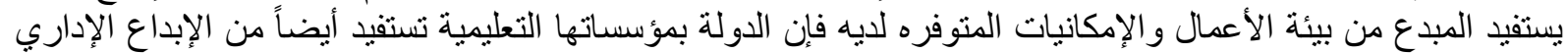

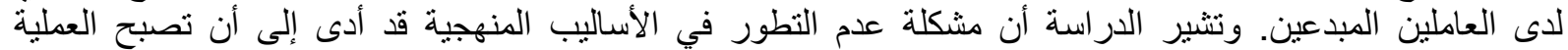

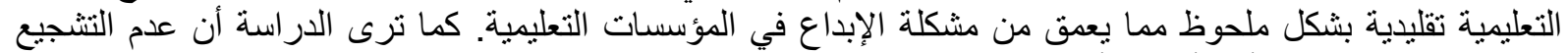

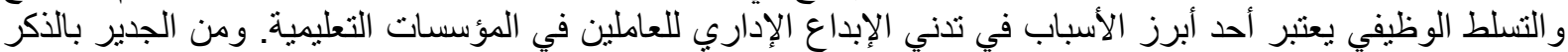

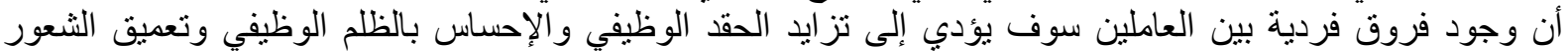

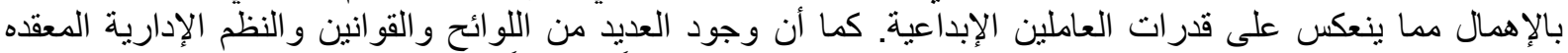

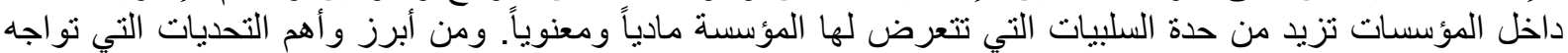

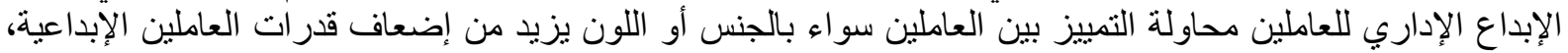

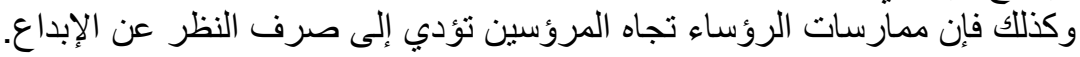

النتائج والتوصيات

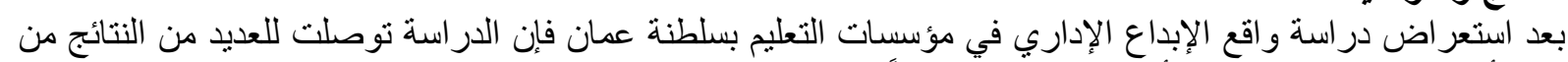

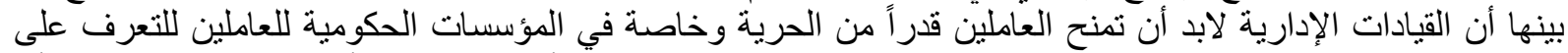

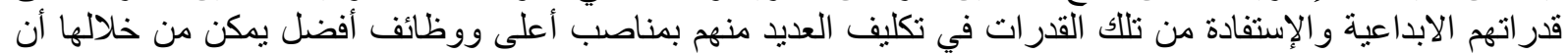

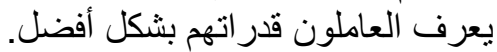

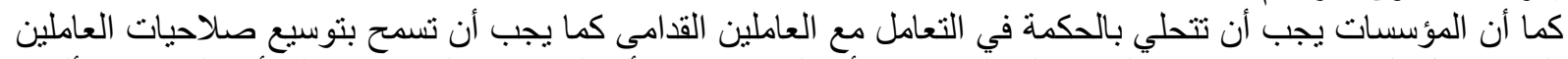

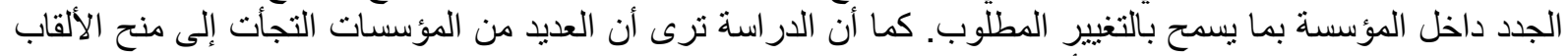

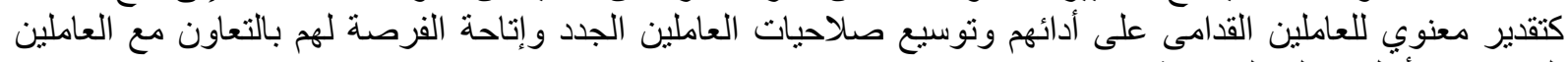
القدامى من أجل صنالح المؤسئة المعائ.

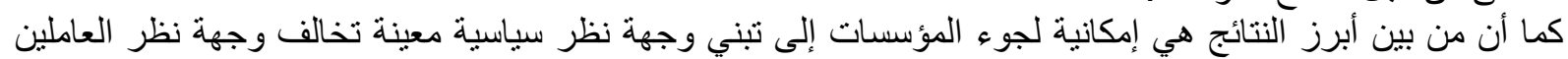

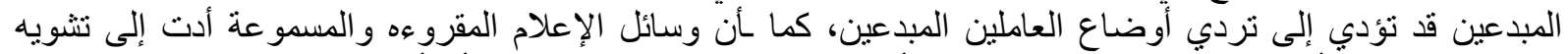

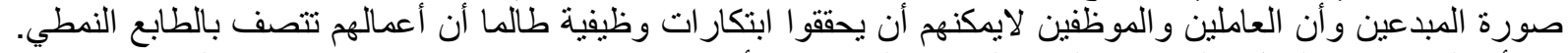

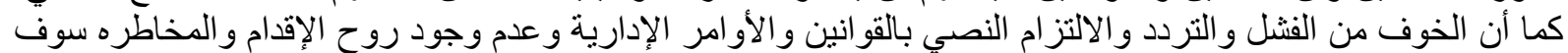

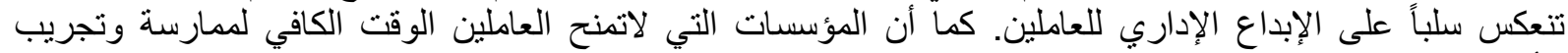

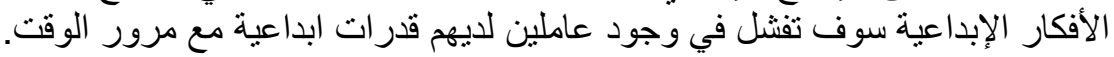

قائمة المراجع والمصادر السودي، سناء راجي أحمد، 2016، درجة الإبداع وعلاقتها بالأداء الإداري لدى مديري المدارس الحكومية في

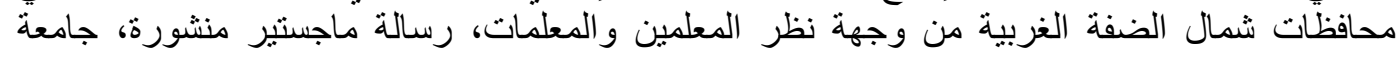
النجاح الوطنية.

إبراهيم، عبد الستار. (2002). الإبداع قضاياه وتطبيقاته، مكتبة الأنجلو المصرية، القاهرة، جمهورية مصر العربية.

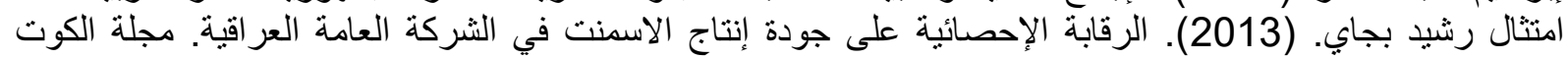

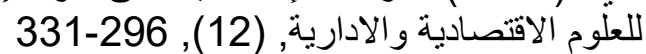

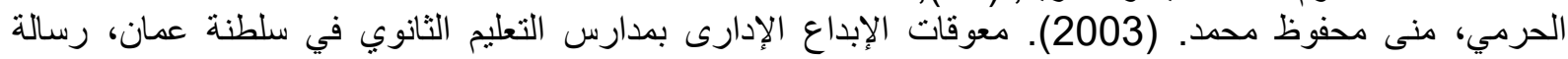
ماجستير، كلية التربية، جامعة السلطان قابوس، سلطنة الإنة عمان.

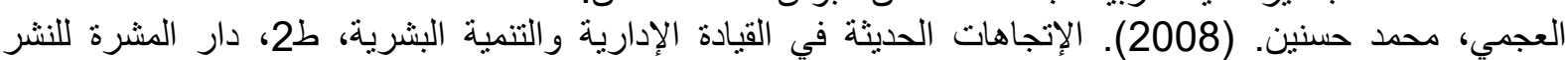
و التوزيع و الطباعة، عمان، الأردن.

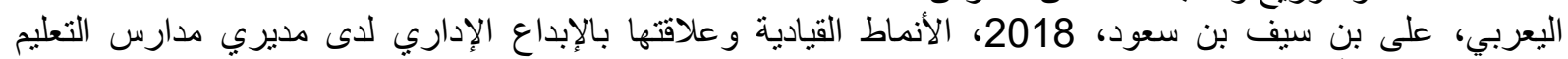

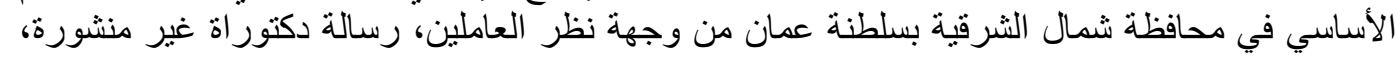


الحارثي، سالم بن سيف بن ناصر. (2014). تصور مقترح لتطوير الإبداع الإداري لاى مديري المدارس في محافظة

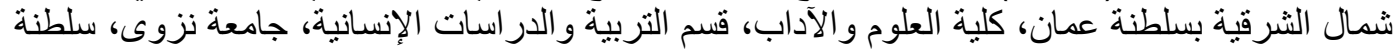

الرشيدي على ضبيان ، 2018، القيادة التحويلية وعلاقتها بالإبداع التنظيمي لدى عمداء ورؤساء الأقسام بالجامعات

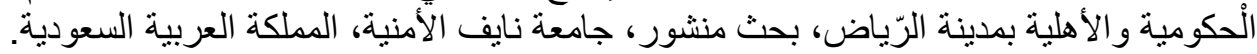

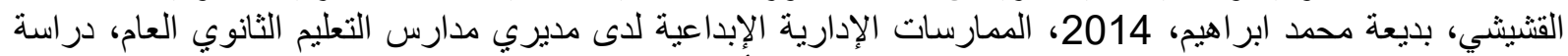

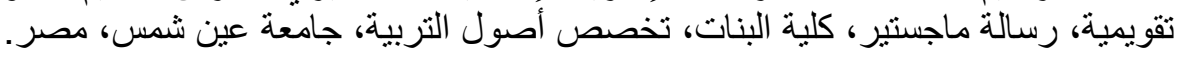

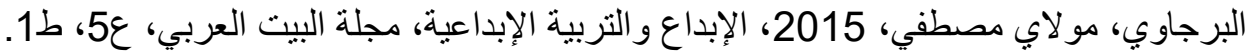

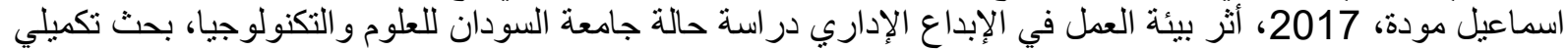

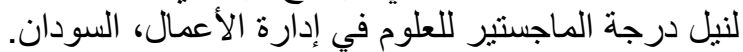

حميدة، عبد القادر على، أمينة، 2014، اتجاهات مديرى المكاتب التنفيذية نحو التفكير الإبتكاري وعلاقتها بالإبداع الإداري

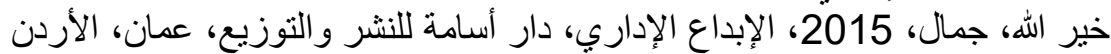

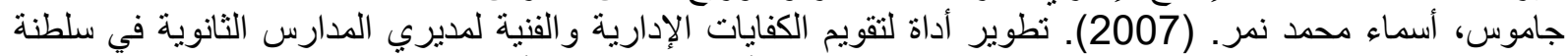
عمان، رسالة ماجستير غير منشورة، الجامعة الأردنية، المملكة الأردنية الهانثمية.

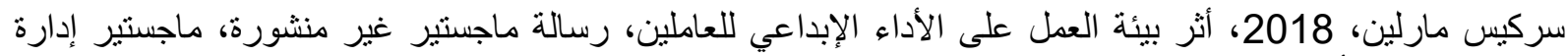
الأعمال، الجامعة السورية الافتراضية اضية، الجمهورية العربية الإبية العاعية السورية.

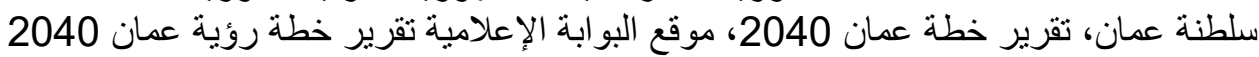
https://www.2040.om/\#Events سلطنة عمان، تقرير خطة عمان 2020،

https://www.gulfpolicies.com/index.php?option=com_content\&view=article\&id=2439\& Itemid $=597$

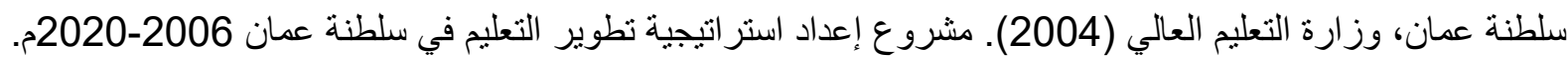

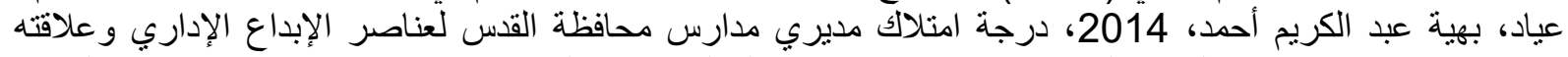

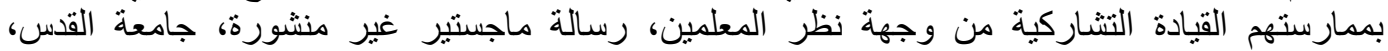
أبوديس، فلسطين. محمدية عمر ، 2016، أثر التمكين الوظيفي في السلوك الإبداعي لدى العاملين في هيئة تتشيط السياجة الأردنية 